\title{
Feminism and social work: Where next for an engaged theory and practice?
}

Viviene Cree University of Edinburgh, United Kingdom

Feminism has never been far from the public eye over the last 10 years or so. Love it or loathe it, it has been out there, fighting to be heard, challenging and, some would argue, reinforcing long-held stereotypes about what it is to be human and live in the world. But what does all this mean for social work and social workers? Is the decision to lay claim to feminism (or not) purely a matter of individual choice, or is there something about social work that is, or should be, fundamentally feminist? This article will interrogate these questions more fully, drawing on research undertaken on feminism and social work over a number of years and also my experience of living and breathing feminism for almost the whole of my life. I start, as all feminists surely must, with my personal story.

\section{The personal is political}

I grew up, the middle one of three girls, in an aspiring middle-class family in Scotland's fourth-largest city, Dundee. When we were small, my parents made the momentous decision to emigrate to New Zealand - to leave behind the none-too-warm climate and hopefully make a better life in a new land. But then my granny became ill, and they were not willing to leave her, so I never knew the highs and lows of emigration. My world remained firmly small-town, East coast Scotland, until I left home to go to university, with fees paid and a maximum grant, the first in my family to enjoy such a privilege.

AOTEAROA NEW ZEALAND SOCIAL WORK 30(3), 4-7.

CORRESPONDENCE TO: Viviene Cree V.Cree@ed.ac.uk
There is so much that can be unpicked about this story...I could reflect on what it was like to grow up in the 1950s in a family of three girls, close in age, with all the delights of closeness and competition that were inevitably part-and-parcel of that childhood.
I could think about my parents' decision not to leave, and what that was about, for my grandparents and for themselves. What were the repercussions of this decision, at the time and then years later? And I could consider the intersections of social class and gender and ethnicity in my story. However I try to make sense of my upbringing, the fact remains. Thanks to my parents, I grew up believing that we-as girls-should not be dependent on a man for our happiness. We should stand on our own feet and make our own successes in life, whatever they might be. We should also care for others-family, friends, community - we had a duty to each other (Christian teaching came to the fore here). And these values were demonstrated and, at the same time, undermined, in all the small and large contradictions and complexities that are inevitably part of growing up.

Leaving home, I found a language for the feelings of injustice that I experienced as a Scottish, grant-aided, female student now living and studying at an ancient university. The women's movement and the "broad Left" became my twin passions, and although my academic grades were never great, I learned a huge amount about life, love and the world. I went on to become a community worker and later social worker, taking with me into adult life all the mélange that had been my life to date. As the popular feminist slogan reminds us: the personal is political. $^{1}$

\section{Feminism and social work}

Social work has had an uneasy relationship with feminism. In some ways, it has always been feminist, in that since its beginnings, it has been concerned with social justice and 
with the well-being and living conditions of those who have lacked power-and this has often meant women and children. So, in the late 19th century when social workers began to set up settlement houses at universities, housing projects in poor parts of cities, and visiting charities for the sick and elderly, their clients were often women, or women and children. And many of the early social workers were also women-upper- and middle-class women who found adventure in charity work, escaping the confines of their constrained lifestyles by engaging in "good deeds". But early social work was, in reality, far from feminist in its aspirations or value-base. The upper- and middle-class social workers saw no contradiction in exploiting the working-class women who looked after their households and children while they engaged in "good works". They also had no qualms about removing children from women who could not afford to look after them in order to give them what they judged to be a "better life". ${ }^{2}$

This story is a familiar one across the developed world, but it is the UK history I know best. As social work became institutionalised through government legislation designed to offer a measure of protection and welfare to individuals and families, so social workers became increasingly employed within local government agencies. At the same time, new voluntary agencies sprang up in the 1960s and 1970s, some, like Women's Aid and Rape Crisis, with an overtly feminist orientation. It is not surprising that, at this time, social work and social workers came under attack, accused by feminist sociologists and psychologists alike of neglecting the needs and rights of women. This was demonstrated in no uncertain terms by the sociologist Mary Maynard's (1985) analysis of social work case-files; she identified that social workers routinely minimised harm, encouraging women to remain in home situations that were often difficult and dangerous.

While social work was being accused by some in the 1980s of being anti-woman and anti-feminist, there were also many social workers at the time who were openly feminist; radical social workers and community workers who sought to bring about change, not only in their work with women, but also in social work with men. Much of the really innovative work happened in projects designed to support women. But criminal justice social work also sought to challenge and change men's negative behaviours, in group work settings especially. Meanwhile across the world, women got together to fight for women's rights, taking on issues such as rape, women's education and, more recently, female genital mutilation. ${ }^{3}$

\section{Student social workers and feminism}

I conducted research on social work students' views of feminism in Edinburgh, Sydney and Auckland in 2008 and 2009, and then again at six universities across the UK in 2013, with the help of my PhD student, Janan Dean. The research showed two prevailing attitudes towards feminism amongst students:
"I'm not a feminist but ..." ("I support women's rights and believe that women should be treated fairly etc.") and "I am a feminist but ..." ("I am not anti-men, segregationalist etc."). (Cree \& Dean, 2015, p. 907)

In reality, there was very little distance between the two sets of opinions; on the contrary, there was a lot of agreement about the issues (which included the importance of women's rights, equality of opportunity, challenging gender-based violence, etc.). The feminism which students identified with was a feminism that was very different to the "bra-burning" stereotypes of "second-wave" Women's Liberation; instead, it was diverse, contradictory, and allowed for individual choice. As one 25-year-old woman said: "There are as many feminisms as there are women. It's a really difficult concept to pin down" (Cree \& Dean, 2015, p. 907). 
Reflecting on this in a journal article published in 2015, Janan and I acknowledged that students and faculty members' experience of feminism may be very different, not least because of differences in age and background. We concluded that there was no single way of being a feminist, just as there was no single way of being a woman. We therefore needed to find ways of opening up conversations about feminism, exploring what a feminist understanding might bring to social work theory, policy and practice. We suggested that feminism offered opportunities to interrogate the everyday and to ground knowledge in experience (Harding, 1987); to question the taken-for-granted and disrupt "settled ways of thinking", to borrow a phrase from Connell (1989, p. xii) (Cree \& Dean, 2015 p. 918).

\section{Recent challenges to feminism}

Ruth Phillips from the University of Sydney and I have written about feminism more recently, firstly in a journal article published in 2014 and then again in a book chapter that will come out in 2019. In the first publication, we considered the place of "fourth wave" feminism in teaching social work, and did so, firstly, by locating the discussion in our herstories - our own autobiographies. These highlighted that, in spite of the geographical distance between us, our paths were very similar. We were, without any shadow of doubt, "typical" feminists: white, middleclass, middle-aged, colonising nation, Western women. We were (so we wrote), illustrative of "the hegemonic danger of the dominant second wave" (Phillips \& Cree, 2014, p. 936). And yet, we had both lived our lives trying to challenge and change both ourselves and feminism. We had brought up sons to be pro-feminist men, we had sought opportunities to work with men and with women, we had conducted research with disadvantaged groups wherever they were located. And in all of this, we had sought to challenge essentialising discourses (which tell us that "women are $\mathrm{x}$ " and "men are $\mathrm{y}$ ").

Our current book chapter takes this analysis even further. Here we argue that the global
North may have lost its way in a deluge of identity politics; it has lost sight of what was, and is, important about feminism. We point out that real and persistent inequalities remain, but these can sometimes be obscured by a policy and practice agenda that seems to have embraced feminism - when male politicians from both the political Right and Left are willing to wear $\mathrm{t}$-shirts that declare themselves to be feminists, what hope is there for feminism as a revolutionary force? We argue that feminism has been co-opted and commodified, at least in Western democratic contexts. Meanwhile, debates within feminism (often expressed through social media) threaten to fracture it completely; quarrels within feminism about emancipation, intersectionality, free speech, sex work, pornography, trans people's rights etc., etc., show no sign of abating. The \#metoo movement which came to public attention in October 2017 and has remained viral ever since is one such manifestation, as women (and some men) highlight sexual harassment and assault while others argue that this campaign distracts from wider issues of power and inequality, and encourages ideas of women's vulnerability and lack of agency.

Ruth and I conclude that it is the global South that reminds us why feminism remains a vital force today. It is here that feminists are engaging on a daily basis with the consequences of the history of colonisation; here racism and sexism go hand-in-hand and here too we can see the emergence of intersectional, anti-racist and decolonising practices that are, we argue, indicative of good social work. We end by quoting the work of Saba Mahmood, who suggests that our scholarly practice should depart "not from a position of certainty but one of risk, critical engagement and a willingness to reevaluate one's own views in light of the Other's" (2001, p. 225). ${ }^{5}$

\section{Finally, looking ahead}

And so we come full circle. I hope I have demonstrated throughout this short article 
that, to grasp the potential for a feminist social work theory and practice in social work, we must first think about why we think this is a good idea, and for whom. What is it that we seek to challenge and change, and why? What is it about us-our personal biographies and backgrounds, our historical moment in time, our class, gender, age, ethnicity, sexuality - that leads us to embrace feminism, whatever we take this to mean? And while we are pursuing a feminist agenda, what are we not seeing? Whose stories are ignored or undermined by our analyses?

Looking ahead, I believe that we must all use the potential that feminism has to speak truth to power-to campaign for social justice and equality, to fight for the human rights of oppressed peoples, and this inevitably means for the rights of women and children. But in doing so, we must also always ask questions about things that we take for granted. In social work terms, this means we must interrogate the very ideas and practices that our profession holds dear, and challenge assumptions, both our own and those of others. This is a great place to start if we are to co-create a truly feminist social work theory and practice in the future.

\section{Notes}

${ }^{1}$ Another version of this story is told in an online blog posted in 2013.

${ }^{2}$ For a fuller account of the various waves of feminism, see Phillips and Cree (2014).

${ }^{3}$ The bibliography includes publications that demonstrate the interest in feminism in social work in the 1980s and 1990s.

${ }^{4}$ Both research studies are discussed in Cree and Dean (2015).

${ }^{5}$ Our chapter will be published in Webb's edited collection in 2019 .

\section{Bibliography}

Brook, E., \& Davis A. (Eds.). (1985). Women: The family and social work. London, UK: Tavistock.

Cavanagh, K., \& Cree, V. E. (Eds.). (1996). Working with men. Feminism and social work. London, UK: Routledge.

Connell, R. W. (1989). Cool guys, wimps and swots, the interplay of masculinity and education, Oxford Review of Education, 15(3), 291-303.
Cree, V. E. (2013). "I've always been a feminist but ..." [Blog post], ESRC Moral Panic Seminar Series, 2012-2014. Retrieved from https://moralpanicseminarseries.wordpress. com/2013/06/26/ive-always-been-a-feminist-but/

Cree, V. E., \& Dean, J. S. (2015). Exploring social work students' attitudes to feminism: Opening up conversations. Social Work Education: The International Journal, 34(8), 903-920. doi:10.1080/02615479.2015.1081884

Cree, V. E., \& Phillips, R. (forthcoming 2019). Feminist contributions to critical social work. In S. A. Webb (Ed.), Routledge handbook of critical social work. London, UK: Routledge.

Dale, J., \& Foster, P. (1986). Feminists and state welfare. London, UK: Routledge and Kegan Paul.

Dobash, R. E., \& Dobash, R. P. (1979). Violence against wives: $A$ case against the patriarchy. New York, NY: Free Press.

Dobash, R. E., \& Dobash, R. P. (1992). Women, violence and social change. London, UK: Routledge.

Dominelli, L., \& McLeod, E. (1989). Feminist social work. Basingstoke, UK: Macmillan.

Hanmer, J., \& Statham, D. (1988). Women and social work: Towards a woman centred practice. London, UK: Macmillan.

Harding, S. (1987). Feminism and methodology. Social science issues. Bloomington IN: Indiana University Press.

Kelly, L. (1987). Surviving sexual violence. Cambridge, UK: Polity Press.

Langan, M., \& Day, L. (1992). Women, oppression and social work: Issues in anti-discriminatory practice. London, UK: Routledge.

Mahmood, S. (2001). Feminist theory, embodiment and the docile agent: Some reflections on the Egyptian Islamic revival. Cultural Anthropology, 16(2), 202-236.

Maynard, M. (1985). The response of social workers to domestic violence. In J. Pahl (Ed.), Private violence and public policy: The needs of battered women and the response of the public services. London, UK: Routledge and Kegan Paul.

Phillips, R., \& Cree, V. E. (2014). What does the "fourth wave" mean for teaching feminism in 21st century social work? Social Work Education: The International Journal, 33(7), 930-943. doi:10.1080/02615479.2014.885007

Phillipson, J. (1992). Practising equality: Women, men and social work. London, UK: Central Council for Education and Training in Social Work.

Wilson, E. (1977). Women and the welfare state. London, UK: Tavistock. 